\title{
TICC GUIDES AVAILABLE FROM NALLD PUBLICATIONS CENTER
}

One of the purposes for which NALLD was founded was to facilitate lab directors helping each other, and sharing their ideas. Making Tape Set TICC GUIDES available through our NALLD Publications Center was a natural extension of this idea.

For the uninitiated, TICC stands for Tape Index Correlation Code. It is a detailed guide which tells how each reel of tape correlates to the printed text by chapter, page, \& type of exercise. Some also give times for each drill. These TICC GUIDES are the heart of a sound information retrieval system for the tape library. They allow both teacher and student to use tapes more effectively in planning a course of study.

Every set of tapes should have such a guide. Since publishers do not always provide them, individual schools make up their own. Through NALLD we can exchange such guides. Here is how the system works:

1. You must be a NALLD member to use this service.

2. Single copies of most TICC GUIDES are available from NALLD FREE, IF you follow these directions exactly.

3. We are unable to provide multiple copies. However, you have our permission to reproduce or copy any material received from the Publications Center provided you identify the source by the line:

-Reprinted by permission of the National Association of Language Laboratory Directors.

4. The TICC GUIDE portion of the Publications Center has been moved to The University of Wisconsin at Madison.

a. Send a $10 \times 13$ inch manila envelope, which is pre-addressed.

b. The envelope must be stamped with sufficient postage for all items requested plus an additional $1 / 2 \mathrm{Oz}$. for the envelope. The weight of each item is listed below.

c. Your request must be on one of our NALLD order blanks which are distributed with each issue of the Journal.

5. In addition to the new guides listed in this issue of the Journal. there are forty-nine (49) other TICC GUIDES in fourteen (14) languages which were listed before in Vol. 4, No. 4 (May, 1970). Note that these were listed by "Category Item Numbers" for ordering purposes from the Publication Center. From now on, all TICC GUIDES will simply be ordered by original TICC Number, Author, \& Title. 
ARABIC-Intermediate

AR 2.006 McCarus, SHORT STORIES

Univ. of Michigan, $1963 \ldots \ldots \ldots \ldots \ldots \ldots$ 1st $\quad .50$

BENGALI-Beginning

BG 1.001 Dimock, AN INTRODUCTION TO BENGALI, Part 1/East-West Center, Hawaii 1964 .... 1 st 2.25

CHINESE-Beginning

CH 1.011 Huang, CANTONESE SOUNDS AND TONES

Far Eastern Publications, Yale U. 1965 .... $\quad$ 1st $\quad .50$

CHINESE-Intermediate

CH 2.002 Chang, READ CHINESE, Book 3

Far Eastern Publications, Yale U. 1961 .... Rev. $\quad .50$

CHINESE-Advanced

CH $3.003 \mathrm{Li}$, READINGS IN CONTEMPORARY CHINESE LITERATURE, Vol. I

Far Eastern Publications, Yale U. 1968 ..... 3 3rd $\quad .75$

CH 3.007 Chih, ADVANCED NEWSPAPER READINGS

Far Eastern Publications, Yale U. 1960 .... 1 . 1 st $\quad .75$

CH $3.009 \mathrm{Li}$, READINGS IN CONTEMPORARY CHI-

NESE LITERATURE, Vol. 2

Far Eastern Publications, Yale U. 1968 .... 3 3rd $\quad .75$

FRENCH-Beginning

FR 1.004 Pond, ECOUTEZ ET DIVINEZ

McGraw Hill, $1965 \ldots \ldots \ldots \ldots \ldots \ldots \ldots$. 1st $\quad .75$

FR 1.007 Wise, LINGUATAPES, Series V

Condor (n.d.) ................... 1st $\quad .75$

FR 1.008 Stack, CLT-Series I-Pattern Drills

Electronic Teaching Laboratories, 1962 ... 1 1st $\quad .75$

FR 1.018 Pucciani, LANGUE ET LANGAGE, Basic Program

Holt, Rinehart and Winston, $1967 \ldots \ldots \ldots$ 1st $\quad 2.50$

FR 1.019 Pucciani, LANGUE ET LANGAGE, Supplementary Program

Holt, Rinehart and Winston, $1967 \ldots \ldots \ldots \ldots$ 1st $\quad 1.00$

FRENCH-Intermediate

FR 2.019 Lenard, L'ART DE LA CONVERSATION

Harper and Row, $1967 \ldots \ldots \ldots \ldots \ldots \ldots$. 1st 1.75

GERMAN-Intermediate

GR 2.013 Griffel, KLEINE DEUTSCHE TYPOLOGIE

Holt, Rinehart and Winston, $1970 \ldots \ldots \ldots . \quad 1$ st $\quad 1.00$ 
JAPANESE-Beginning

JA 1.006 Bloch, SPOKEN JAPANESE

Holt, Rinehart and Winston, $1945 \ldots \ldots \ldots$. 1st $\quad .75$

JA 1.008 Jordan, BEGINNING JAPANESE, Part 1

Yale University Press, $1962 \ldots \ldots \ldots \ldots \ldots$ 1st 2.00

JA 1.010 Jordan, BEGINNING JAPANESE, Part 2

Yale University Press, $1962 \ldots \ldots \ldots \ldots \ldots$ 1st 2.00

PERSIAN-Beginning

PE 1.002 Obolensky, PERSIAN BASIC COURSE

Center for Applied Linguistics, 1963 ...... 1 1st $\quad .75$

RUSSIAN-Advanced

RU 3.001 Townsend, CONTINUING WITH RUSSIAN

McGraw Hill, $1970 \ldots \ldots \ldots \ldots \ldots \ldots \ldots$. 1st $\quad .75$

SPANISH-Beginning

SP 1.031 Wolfe, CURSO BASICO DE ESPANOL Macmillan, $1970 \ldots \ldots \ldots \ldots \ldots \ldots \ldots$. 1st 1.50

SP 1.032 Dobrian, SPANISH READINGS FOR CONVERSATION

Houghton Mifflin, $1970 \ldots \ldots \ldots \ldots \ldots$. 1st 1.00

SPANISH-Intermediate

SP 2.022 Altabe, TEMAS Y DIALOGOS

Holt, Rinehart and Winston, $1970 \ldots \ldots \ldots$. 1st $\quad .50$

SP 2.024 Hesse, SPANISH CONVERSATIONAL REVIEW GRAMMAR

Van Nostrand, $1970 \ldots \ldots \ldots \ldots \ldots \ldots \ldots$ 3rd 1.75

NALLD Order Blank for TICC GUIDES

Send this order blank, along with a $10 \times 13$ manila envelope which is self-addressed and STAMPED with the proper return postage (according to the weight of materials ordered plus $1 / 2 \mathrm{oz}$. for envelope) to:

Mr. T. R. Goldsworthy, Director

Language Laboratories

University of Wisconsin

Van Hise Hall, 1220 Linden Drive

Madison, Wisconsin 53706 
NALLD Order Blank for TICC GUIDES

Send this order blank, along with a $10 \times 13$ manila envelope which is self-addressed and STAMPED with the proper return postage (according to the weight of materials ordered plus $1 / 2 \mathrm{oz}$. for envelope) to:

Mr. T. R. Goldsworthy, Director

Language Laboratories

University of Wisconsin

Van Hise Hal1, 1220 Linden Drive

Madison, Wisconsin 53706

\begin{tabular}{|l|l|l|l|}
\hline TICC NUMBER & LANGUAGE & AUTHOR \& TITLE & $\begin{array}{c}\text { WEIGHT } \\
\text { IN OZ. }\end{array}$ \\
\hline & & & \\
\hline & & & \\
\hline & & & \\
\hline & & & TOTAL WEIGHT: \\
\hline
\end{tabular}

Name :

School:

Address :

City \& state:

2IP CODE :

FOP OFFICE USE:

Date request received:

Date guides sent:

I AM A MEMBER OF NALLD 